\title{
Neoadjuvant Chemotherapy for Colorectal Liver Metastases
}

\author{
Pamela C. Hebbard, Yarrow J. McConnell and Oliver F. Bathe \\ University of Calgary \\ Canada
}

\section{Introduction}

Over the last decade, since the development of improved systemic agents for colorectal cancer, there has been increasing exploration of the use of neoadjuvant strategies for colorectal liver metastases (CRLM). In some cases, upfront chemotherapy enables downsizing, in order to enhance resectability. In other cases, neoadjuvant chemotherapy is a means to expedite delivery of systemic therapy and perhaps also to select patients for subsequent treatments.

\section{Surgical management of colorectal liver metastases}

Since the 1980s, hepatectomy has been increasingly performed for patients with liver-only metastases from colorectal cancer. The first large series were published in the 1990s, demonstrating 5 -year survival of $25-40 \%$ for patients who underwent R0 resections. These compared favorably with the $0-5 \%$ survival rates for patients with technically resectable disease who did not undergo resection, or who had positive margins at resection (R1 or R2) (Scheele \& Altendorf-Hofmann, 1999). The patients included in these early series where a highly select group, mostly with solitary lesions less than $5 \mathrm{~cm}$ in diameter. However, from these data the initial guiding principles of surgery for CRLM were developed: a) exclusion of patients with any extra-hepatic metastases; b) removal of all detectable liver metastases while providing sufficient residual liver volume for postoperative function; and c) achievement of negative margins (R0 resection; Fong et al., 1997).

With advancements in preoperative staging, surgical techniques, and multimodality treatment since that time, this definition of resectability has been greatly expanded. Current approaches extend the possibility of surgical resection to patients with CRLM involving: both lobes of the liver; large/multiple lesions requiring extended hepatectomies; and extra-hepatic sites, particularly pulmonary (Yang et al., 2010). For practical purposes, the only remaining limits on the definition of "resectable" are the achievement of negative margins, preservation of adequate remnant liver (minimum 20\% with a healthy liver) with vascular and biliary inflow/outflow, and capacity of the patient to tolerate the planned, often multimodality, treatment (Charnsangavej et al., 2006; Nordlinger et al., 2009).

Even with these expanded resection criteria and increasingly aggressive surgical strategies, survival rates have continued to improve. Recent large series report 5-year overall survival of $53-58 \%$ and 5-year recurrence-free survival of 28 - 36\% (Abdalla et al., 2004; Choti et al., 2002; Fernandez et al., 2004; Figueras et al., 2001; Pawlik et al., 2005). These series are 
predominantly from highly specialized institutions. Studies of national administrative databases, over the same time period, report a more modest 5-year overall survival of 22 $33 \%$ following hepatectomy (Cummings et al., 2007; Robertson et al., 2009; Wang et al., 2007). In all studies, whether single centre or population based, the great majority of patients undergoing surgery also received preoperative and/or postoperative chemotherapy. The integration of medical and surgical therapies, with advances in each, and improvements in our ability to effectively and safely combine modalities, has undoubtedly contributed to the observed improvement, or at least stability, of survival rates despite the inclusion of patients with increasingly advanced disease.

Although the presence of extra-hepatic metastases continues to be associated with worse overall survival, aggressive multi-site resection strategies, in combination with chemotherapy, have achieved 5-year survival rates of $19-28 \%$ at specialty centres (Adam et al., 2011; Carpizo \& D'Angelica, 2009; Figueras et al., 2007). Surgical candidates with multisite metastases are often treated with several cycles of chemotherapy and then resected, often with multiple operations, if they show stable or responsive disease. Those with only pulmonary extra-hepatic metastases are the most commonly treated in this fashion but emerging data suggests that indicators of tumor biology and total number of metastatic sites are stronger predictors of survival than the actual sites of metastatic disease, assuming that complete resection can be achieved (Adam et al., 2011).

Prior to resection of liver metastases, patients undergo detailed radiographic examination of the liver by either CT or MRI. In many centres, PET-CT imaging is obtained on all patients with potentially resectable liver lesions. The addition of PET imaging has been shown to alter management in $10-30 \%$ of patients, usually by the detection of previously unknown extra-hepatic lesions (Charnsangavej et al., 2006). With all types of imaging, evaluation by an experienced hepatobiliary radiologist is an important part of surgical, chemotherapeutic, and other treatment planning.

Patients with synchronous liver metastases at the time of their primary tumor diagnosis require individualized decision-making regarding surgery and any neoadjuvant chemotherapy. In the case of an obstructing primary tumor or a patient with significant anemia, a surgical approach to address the primary tumour is usually required prior to consideration of chemotherapy and/or resection of CRLM. In asymptomatic patients, staged or combined resections of the primary and metastatic lesions can be considered, with similar perioperative outcomes and survival in large retrospective series (de Haas et al., 2010; Lyass et al., 2001; Martin et al., 2009). One clinical trial is currently accruing patients in an attempt to address this question prospectively (Rennes University Hospital, 2009). Decision-making regarding the surgical approach depends on the complexity of each part of the surgery, the surgeons' experience, the patient's ability to tolerate lengthy and complex surgery, and logistical factors (Charnsangavej et al., 2006). Neoadjuvant chemotherapy is now frequently offered to these patients. Overall, survival appears to be similar between the various approaches, although no prospective trials have considered this question (Brouquet et al., 2010). In patients with bilobar CRLM or in whom resection of all lesions would leave an insufficient future liver remnant (FLR), several surgical and interventional techniques are available to convert the patient to a resectable state. Hypertrophy of the FLR can be achieved by ligating or embolizing the portal vein feeding the diseased lobe(s) of the liver (Figure 1). If on repeat imaging, $4-6$ weeks following portal vein embolization (PVE), the FLR has adequately hypertrophied, patients can undergo extended hepatectomy with perioperative 
A
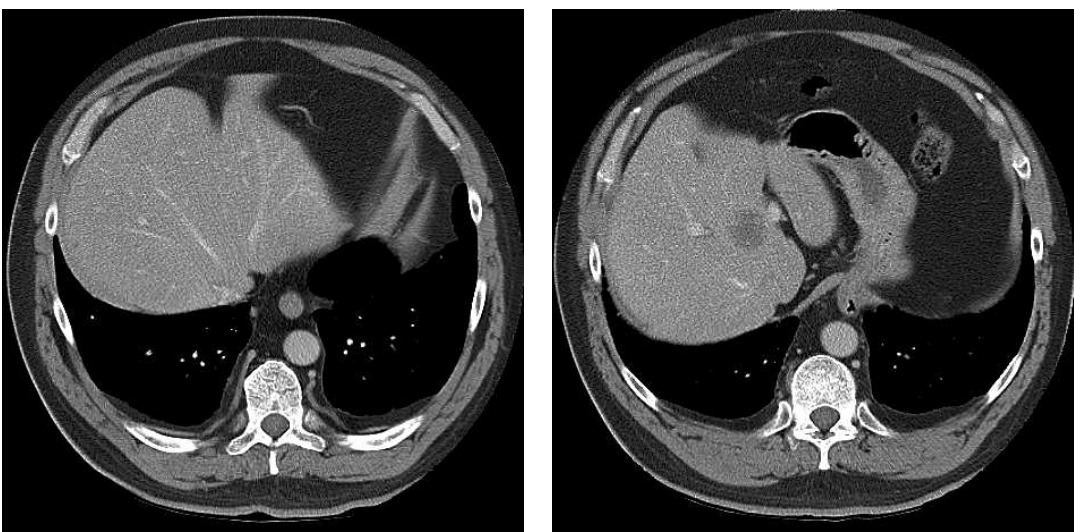

B
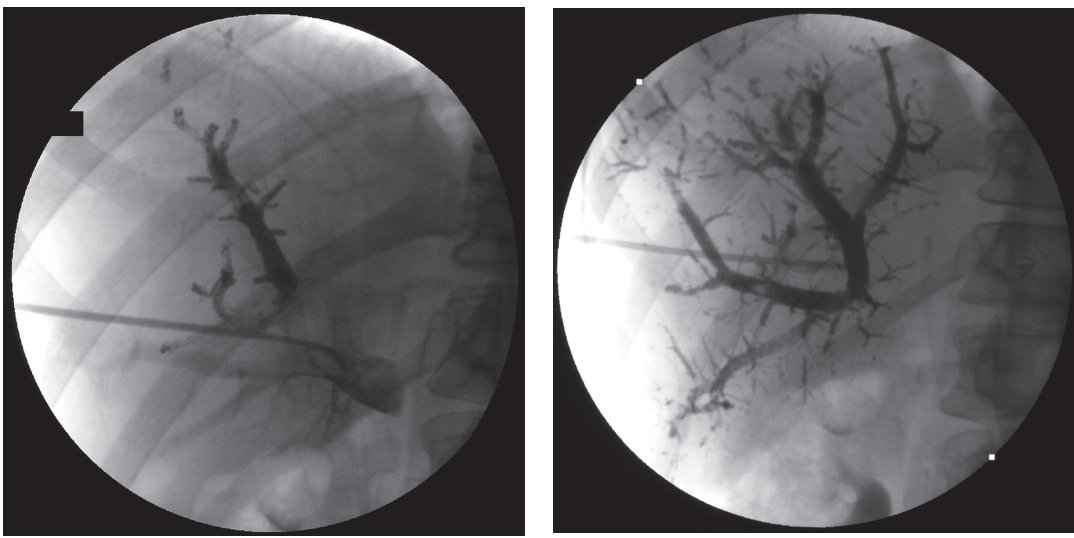

C
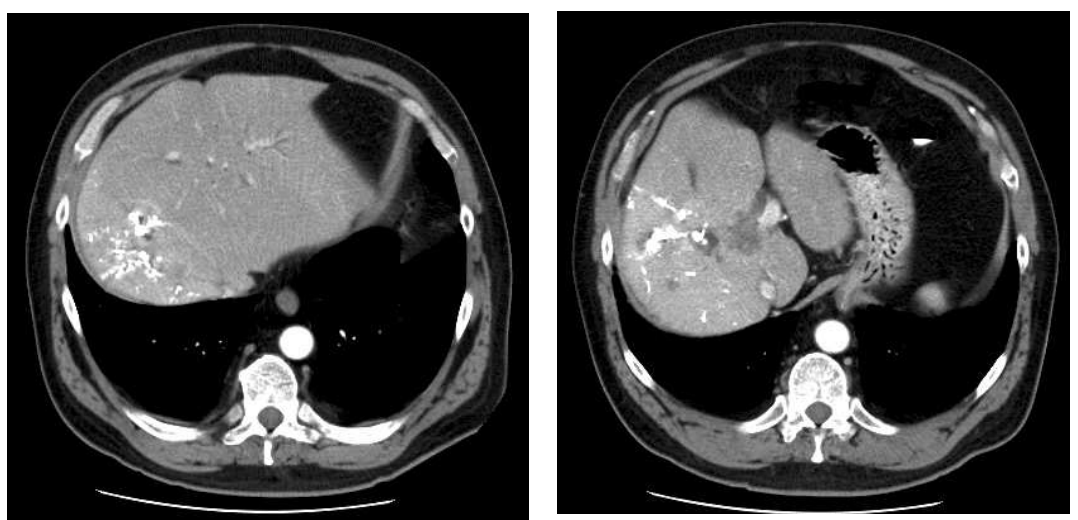

Fig. 1. Portal vein embolization is used to induce hypertrophy of the liver remnant. The lobe or segments containing the liver metastases (and to be resected) is embolized, if it is anticipated that the remaining liver will be too small to provide adequate functional hepatic reserve (A, B). After $4-6$ weeks, the non-embolized segments of liver will hypertrophy (C), allowing an extensive liver resection with a greater margin of safety. 
outcomes and long-term survival similar to that in patients who did not require PVE (Abdalla et al., 2006; Yang et al., 2010). One contraindication to PVE is the presence of lesion(s) in the FLR, due to the risk of progression with hypertrophy. In these cases, a staged approach to resection may be possible. At the initial operation, the lesion(s) in the FLR are resected and the portal vein to the remainder of the diseased liver is ligated. If the patient recovers well and sufficient hypertrophy is achieved, a second laparotomy with extended hepatectomy is undertaken 6 - 12 weeks later. Perioperative morbidity and long-term survival with this approach appears to be similar to that of patients with a similar burden of disease who achieve complete resection with a single hepatectomy (Chun et al., 2007; Wicherts et al., 2008; Yang et al., 2010). The administration of chemotherapy has been successfully implemented with all of these approaches - preoperatively, between staged operations, and postoperatively. The relative contribution of surgical and chemotherapeutic components of these complex management algorithms is unknown. However, as in the more straightforward clinical scenarios discussed in detail below, any evidence of disease progression while on chemotherapy is usually cause for re-evaluation of any further surgical intervention.

When complete surgical resection cannot be achieved, even with the use of adjuncts such as PVE and staged hepatectomies, radiofrequency ablation (RFA) can be used in conjunction with hepatectomy. When compared head-to-head for single lesions, RFA has a significantly higher recurrence rate and is inferior to resection (Aloia et al., 2006a). However, in the era of modern chemotherapy, patients with multiple lesions treated with a combination of resection and RFA, long-term survival rates similar to those of patients with complete resection have been achieved (Nikfarjam et al., 2009). This suggests that in patients with CRLM that are stable or regressing on chemotherapy, but which remain technically unresectable, an approach that includes resection and RFA may be considered.

The final surgical scenario worth noting in the context of CRLM is the patient with synchronous disease who stabilizes or responds to neoadjuvant chemotherapy but whose liver disease remains unresectable. These patients may have an extended survival and the question often arises whether there is value in resecting their primary lesion. Data supporting a survival benefit from such a resection come from series that pre-date modern chemotherapy (Cook et al., 2005; Ruo et al., 2003). With the prolonged survival offered by current chemotherapy regimens, any added benefit is more likely to be related to prevention of local morbidity. The likelihood of developing obstruction and/or pain from local invasion appears to be greatest in patients with rectosigmoid lesions. Therefore, prophylactic resection, particularly when it can be achieved with minimal morbidity, is likely of benefit in this group of patients (Scheer et al., 2008). In all others, the chance of requiring emergent palliative surgery appears to be minimal and decisions regarding resection are made on an individual basis (Cellini et al., 2010).

In general, the surgical management of CRLM is becoming more complicated and more aggressive. Partly, this is due to technical advances in hepatobiliary surgery. Perhaps of greater import is the development of newer systemic agents with greater activity against metastatic colorectal cancer.

\section{Systemic agents used for metastatic colorectal cancer}

Modern chemotherapy for metastatic colorectal cancer is typically a multi-drug regimen. Doublet regimens of a fluoropyrimidine combined with either oxaliplatin or irinotecan are highly effective in metastatic and adjuvant colorectal cancer. The addition of a targeted biologic agent further increases response rates in appropriate metastatic patients (Compton et al., 2008; Douillard et al., 2010; Folprecht et al, 2010). 
Fluorouracil is a pyrimidine analog developed in the 1950s. It functions to interrupt DNA synthesis by inhibiting DNA methylation. Fluorouracil can be given in an intravenous form, 5-FU, or orally via capecitabine, which is subsequently metabolized to an active molecule. When given in IV formulation, fluorouracil is commonly combined with the folate derivative, leucovorin, to enhance its function.

Irinotecan (also known as CPT-11) was approved for use in metastatic colorectal cancer in the mid-1990s. It is an inhibitor of topoisomerase I, a complex that reduces the torsional strain on DNA by breaking, detorting and reconnecting single strands of DNA. Irinotecan's action on topoisomerase I allows single strand breaks to accumulate, ultimately leading to cell cycle arrest and cell death.

Oxaliplatin was introduced to the global market in the late 1990s. It is a platinum-based compound that cross-links DNA, preventing its replication and transcription. The 5-FU, leucovorin, and oxaliplatin combination, FOLFOX, is highly effective in the metastatic setting, but its long-term use is limited by a cumulative dose-dependent side effect of peripheral sensory neuropathy.

Novel biologic agents have been recently introduced into clinical use and are monoclonal antibodies to proteins key to tumor growth pathways. Bevacizumab is a fully humanized antibody against vascular endothelial growth factor (VEGF), and results in inhibition of tumor angiogenesis. Cetuximab and panitumumab are antibodies to the human epidermal growth factor receptor (EGFR; also called HER1). EGFR blockade inhibits cell growth and induces apoptosis. Mutations of the KRAS gene, downstream from EGFR, negate the potential effects of EGFR inhibitors, and so only patients with wild-type KRAS benefit from this treatment (Karapetis et al., 2008). These medications are generally well tolerated, although rare but concerning side effects have been documented (Table 1B). As all of these agents are new to clinical use, their side effect profiles are likely to be refined over time.

\begin{tabular}{|c|c|c|c|}
\hline Agent & Fluorouracil & Irinotecan & Oxaliplatin \\
\hline $\begin{array}{l}\text { Common } \\
\text { Side } \\
\text { Effects }\end{array}$ & $\begin{array}{l}\text { Nausea/Vomiting } \\
\text { Diarrhea } \\
\text { Stomatitis } \\
\text { Hand-foot syndrome } \\
\text { Bone marrow } \\
\text { suppression } \\
\text { Hyperbilirubinemia }\end{array}$ & $\begin{array}{l}\text { Nausea/Vomiting } \\
\text { Diarrhea } \\
\text { Abdominal pain } \\
\text { Bone marrow suppression } \\
\text { Hair loss } \\
\text { Asthenia }\end{array}$ & $\begin{array}{l}\text { Nausea/Vomiting } \\
\text { Diarrhea } \\
\text { Peripheral sensory } \\
\text { neuropathy } \\
\text { Stomatitis } \\
\text { Bone marrow suppression }\end{array}$ \\
\hline $\begin{array}{l}\text { Rare } \\
\text { Side } \\
\text { Effects }\end{array}$ & $\begin{array}{l}\text { Cardiac complications } \\
\text { Liver fibrosis/failure }\end{array}$ & $\begin{array}{l}\text { Colitis/ ileitis/ bowel } \\
\text { perforation } \\
\text { Thromboembolic events } \\
\text { Liver impairment, } \\
\text { including SOS }\end{array}$ & $\begin{array}{l}\text { Thromboembolic events } \\
\text { Liver impairment, } \\
\text { including CASH }\end{array}$ \\
\hline
\end{tabular}

Table 1A. Side effects of cytotoxic agents used in metastatic colorectal cancer.

An overview of the side effect profiles of each of these drugs is given in Table 1. Of particular interest is the potential of chemotherapy to induce specific liver toxicity in the setting of future liver surgery, discussed further below. 


\begin{tabular}{|c|c|c|c|}
\hline Agent & Bevacizumab & Cetuximab & Panitumumab \\
\hline $\begin{array}{c}\text { Common } \\
\text { Side } \\
\text { Effects }\end{array}$ & $\begin{array}{l}\text { Hypertension } \\
\text { Bleeding } \\
\text { Abdominal pain } \\
\text { Asthenia } \\
\text { Nausea/Vomiting } \\
\text { Diarrhea/constipation }\end{array}$ & $\begin{array}{l}\text { Rash } \\
\text { Infusion/hypersensitivity } \\
\text { reactions } \\
\text { Headache } \\
\text { Abdominal pain } \\
\text { Nausea/vomiting } \\
\text { Diarrhea/constipation } \\
\text { Bone marrow suppression }\end{array}$ & $\begin{array}{l}\text { Rash } \\
\text { Infusion/hypersensitivity } \\
\text { reactions } \\
\text { Abdominal pain } \\
\text { Nausea/vomiting } \\
\text { Diarrhea/constipation } \\
\text { Asthenia } \\
\text { Peripheral edema } \\
\end{array}$ \\
\hline $\begin{array}{c}\text { Rare } \\
\text { Side } \\
\text { Effects }\end{array}$ & $\begin{array}{l}\text { GI perforation } \\
\text { GI fistula } \\
\text { Delayed wound healing } \\
\text { Congestive heart failure } \\
\text { Thromboembolism }\end{array}$ & $\begin{array}{l}\text { Respiratory complications } \\
\text { Cardiopulmonary Arrest }\end{array}$ & Respiratory complications \\
\hline
\end{tabular}

Table 1B. Side effects of biologic agents used in metastatic colorectal cancer.

\section{Rationale for neoadjuvant chemotherapy}

Neoadjuvant chemotherapy could be considered in instances where the CRLM are resectable, or when CRLM are not technically resectable. The rationale for giving upfront chemotherapy for each of these circumstances differs, which bears some discussion.

\subsection{Unresectable colorectal liver metastasis}

The utility of using chemotherapy to downstage CRLM which are unresectable to a resectable status was first described by Bismuth et al (1996). Since then, in the setting of unresectable CRLM, unless some adjunctive approach such as PVE or two-stage hepatectomy is considered, all patients with unresectable CRLM should be considered for chemotherapy. After detailed imaging, chemotherapy is administered for $2-6$ cycles, and then repeat detailed imaging is performed to evaluate for response. Patients with a response significant enough to make them candidates for resection are then reconsidered for surgery. Patients whose liver lesions do not respond or progress on chemotherapy continue on palliative-intent chemotherapy, with consideration for second-line and/or clinical trial agents.

This approach has several benefits. Firstly, it defines a group of responders whose tumor biology is more favorable, and in whom aggressive resection is most likely to be of benefit. Secondly, it provides an in vivo measurement of the effectiveness of the given chemotherapy regimen for a given patient. Depending on the response, decisions can then be made about continuing with the same agents or switching regimens - either as adjunctive therapy following surgery, or as palliative-intent chemotherapy when surgery is not possible.

\subsection{Resectable colorectal liver metastasis}

In patients with initially resectable CRLM, the decision to administer upfront chemotherapy is much more complicated. A neoadjuvant chemotherapy approach has some advantages. First, it allows the delivery of systemic treatment early in the patient's treatment course. Occult or micrometastatic disease is treated before it becomes clinically visible, when the burden of disease is low. Neoadjuvant therapy further allows the patient to receive chemotherapy during optimal health, as undoubtedly some surgical patients will experience 
morbidity that will delay or preclude the administration of cytotoxic drugs. Secondly, neoadjuvant chemotherapy allows the clinician to assess tumor biology. Response to chemotherapy can be measured on serial imaging. Progression of disease, whether in or outside the liver, indicates resistance to the chemotherapy regimen used and thus provides the opportunity to select an alternative combination that may be more effective. Progression of disease while on chemotherapy is an independent predictor of worse survival and liver surgery may not be beneficial in this population (Adam et al., 2004b). Thus, this information further aids in selection of appropriate liver surgery patients.

There are also some disadvantages that accompany neoadjuvant chemotherapy for CRLM. First, current chemotherapy regimens have the potential for liver damage. This risk is mitigated by careful monitoring and by limited durations of pre-operative chemotherapy. Secondly, disease progression on chemotherapy may preclude some patients who were initial surgical candidates from liver resection. This has been a rare event in trials of neodjuvant chemotherapy, and likely portends a worse overall prognosis (Nordlinger et al., 2008; Bathe et al., 2009). Thus, it may actually spare patients from surgery if they are unlikely to achieve a survival benefit. Finally, up-front chemotherapy may cause some tumors to disappear completely, making subsequent decision-making more difficult. These challenges are discussed in more detail in Section 5.

\section{Clinical trials}

\subsection{The role of neoadjuvant chemotherapy in unresectable liver-only metastases}

Chemotherapy has long been used as the sole treatment modality for patients with CRLM, with the goal of palliation and the prolongation of life by a few months. With the finding that hepatectomy can lead to long-term survival in $30-40 \%$ of patients, this goal changed. In initially unresectable patients, chemotherapy is now used with the aim of downstaging lesions to the point of resectability. If this is not achievable, then the goal shifts towards more traditional palliative-intent treatment.

Clinical trials in the setting of liver-only metastases have thus begun to focus on determining the optimal chemotherapy regimen, in terms of maximizing response and resection rates, and also in terms of minimizing perioperative morbidity associated with the effects of intensive preoperative chemotherapy. In early cohort and phase II studies of unresectable patients, treatment with 5-FU, leucovorin and oxaliplatin and/or irinotecan (FOLFOX/FOLFIRI) led to a measurable response rate of $59-72 \%$ and achievement of margin-negative resections in 12$38 \%$ of patients (Giachetti et al., 1999; Adam et al., 2004a; Masi et al., 2009). In patients undergoing resection after downstaging, median survival from the start of chemotherapy was 37 - 48 months, compared to 14 - 15 months in those who did not respond sufficiently to allow resection and/or were not candidates for resection following chemotherapy. These results were obtained with the administration of, on average, 10 - 12 cycles of chemotherapy over a 5 6 month period. No perioperative deaths were reported in these studies, although Masi et al. (2009) reported a perioperative morbidity rate of $27 \%$ including $8 \%$ transient liver failure.

Two phase II trials have evaluated tumor response and secondary resection rates with the addition of biologic agents to FOLFOX/FOLFIRI chemotherapy. In initially unresectable patients, Wong et al. (2011) reports an objective response rate of $40 \%$ and a margin-negative resection rate of $10 \%$ after administration of capecitabine, oxaliplatin, and bevacizumab $(\mathrm{CAPOX}+\mathrm{B})$. With only 12 months of follow-up reported, median survival times have not been reached in this study. Of note, patients in this study received a median of only 4 cycles of preoperative $\mathrm{CAPOX}+\mathrm{B}$ and 2 patients who achieved a complete response did not 
undergo resection. Bevacizumab was stopped, on average, 10 weeks prior to hepatectomy but a $4 \%$ rate of grade 2 or 3 intestinal perforation was reported. Overall, the perioperative morbidity rate was $28 \%$, with no liver failure events reported.

In the CELIM trial (Folprecht et al., 2011), patients with unresectable CRLM were randomized to cetuximab plus either FOLFOX or FOLFIRI. The objective response rate was $62 \%$, with a $70 \%$ response rate in the subset of patients who were K-ras wildtype - a known predictor of responsiveness to cetuximab. The overall margin-negative resection rate was $34 \%$ and patients received a median of 8 treatment cycles over a 5-month period prior to surgery. Survival data have not yet been published. Perioperative mortality was $4 \%$ and major morbidities occurred in $35 \%$.

The addition of bevacizumab has not been conclusively shown to improve response rate or resectability rate, either in the phase II trial reviewed here or, as a secondary end-point in phase III trials (Saltz et al., 2008). On the other hand, the response rates reported in the CELIM trial are quite compelling reasons to consider cetuximab-containing regimens when attempting to downstage unresectable liver metastases, particularly in K-ras wildtype patients.

With modern chemotherapeutic regimens, usually incorporating oxaliplatin or irinotecan and biologic agents, responses to chemotherapy are well over 50\% (Folprecht et al., 2010; Gruenberger, 2008a, 2008b). Downstaging of initially unresectable disease to resectable disease occurs in 13 - 40\% of patients with liver-only metastases who have received systemic chemotherapy (Table 2 and Table 3 ). Higher rates of conversion to resectability are generally reported in surgical series (Table 3). The wide range of incidences of conversion of unresectable liver metastases to a resectable status is partly a function of the variations in definitions of resectability among surgeons and other oncologic specialties. This phenomenon was well illustrated in the series by Folprecht et al. (2010).

\begin{tabular}{|l|c|c|c|c|}
\hline \multicolumn{1}{|c|}{ Reference } & Agents & N & RR (\%) & $\begin{array}{c}\text { Liver Resection } \\
\text { (\%) }\end{array}$ \\
\hline Levi et al., 1999 & 5-FU, LV, Oxaliplatin & 90 & 66 & 34 \\
\hline De Gramont et al., 2000 & 5-FU, LV, Oxaliplatin & 210 & 54 & 7 \\
\hline Giacchetti et al., 2000 & 5-FU, LV, Oxaliplatin & 100 & 53 & 32 \\
\hline Scheithauer et al., 2003 & Capecitabine, Oxaliplatin & 89 & 48 & 9 \\
\hline Teufel et al., 2004 & 5-FU, LV, Irinotecan & 35 & 31 & 9 \\
\hline Tournigand et al., 2004 & FOLFIRI $\rightarrow$ FOLFOX & 109 & 56 & 9 \\
\hline Sorbye et al., 2004 & FOLFOX $\rightarrow$ FOLFIRI & 111 & 54 & 22 \\
\hline Bajetta et al., 2004 & 5-FU, LV, Oxaliplatin & 82 & 62 & 11 \\
\hline Cassidy et al., 2004 & Capecitabine, Irinotecan & 140 & 46 & 6 \\
\hline Kohne et al., 2005 & Capecitabine, Oxaliplatin & 96 & 55 & 5 \\
\hline Falcone et al., 2007 & 5-FU, LV, Irinotecan & 214 & 62 & 7 \\
\hline Tabernero et al., 2007 & FOLFIRI & 122 & 41 & 6 \\
\hline
\end{tabular}

Table 2. Incidence of successful hepatic metastasectomy in first-line chemotherapy trials.

Overall, these experiences have served to make response and resection rates important end points in trials of new chemotherapeutic agents for CRLM. Downstaging unresectable liver- 
only disease followed by surgery is accompanied by reasonable perioperative complication rates and has become the accepted standard.

\begin{tabular}{|l|c|c|c|}
\hline \multicolumn{1}{|c|}{ Reference } & Agents & N & Liver Resection (\%) \\
\hline Adam et al., 2001 & Mostly oxaliplatin-based & 701 & 13.5 \\
\hline Rivoire et al., 2002 & 5-FU, LV, Oxaliplatin & 131 & 44 \\
\hline Moehler et al., 2003 & 5-FU, LV, Irinotecan & 46 & 6.5 \\
\hline Pozzo et al., 2004 & 5-FU, LV, Irinotecan & 40 & 32.5 \\
\hline Delaunoit et al., 2005 & 92\% oxaliplatin-based & 795 & 3.3 \\
\hline Masi et al., 2006 & FOLFOXIRI & 74 & 26 \\
\hline \multirow{2}{*}{ Folprecht et al., 2010 } & FOLFIRI + cetuximab & 55 & 38 \\
& FOLFOX + cetuximab & 56 & 40 \\
\hline
\end{tabular}

Table 3. Rates of successful liver resection in surgical series where neoadjuvant chemotherapy was used to downstage tumour bulk.

\subsection{The role of neoadjuvant chemotherapy in resectable colorectal liver metastases}

There are few clinical trials of neodjuvant chemotherapy in the upfront resectable setting. The EORTC 40983 trial provides the only level I evidence for its use (Nordlinger et al., 2008). This trial enrolled 364 patients with up to four colorectal liver metastases to receive perioperative chemotherapy and liver resection versus surgery alone. The chemotherapy consisted of 12 cycles of FOLFOX4, with half given pre-operatively and half postoperatively. In the chemotherapy arm, 80 percent of patients completed the preoperative schedule and $70 \%$ completed the entire regimen. At the time of surgery, $3 \%$ had a complete response, $40 \%$ a partial response, and $38 \%$ stable disease. Only 8 patients had progression that precluded surgery. Ultimately, 3 year progression-free survival went from 28.1 months in the surgery arm to 35.4 months in the multimodality arm, for a hazard ratio of 0.79 . Final analysis of overall survival is still pending.

A similar trend has been seen in nonrandomized trials. Bathe et al. (2009) published a phase II trial of 5-FU, leucovorin, and irinotecan as pre-operative chemotherapy for patients with resectable liver metastases. The study enrolled 35 patients, of whom 76 percent had responsive or stable disease during chemotherapy. Thirty-one patients went to surgery, with 30 patients having R0 resection. Post-operative chemotherapy was also delivered to 22 patients. Median disease-free survival (DFS) was 23 months and 2 year DFS was 47 percent. The study was halted early due to a high rate of thromboembolic complications. Meanwhile, Watkins et al. (2010) employed a strategy of neoadjuvant capecitabine and oxaliplatin in a heterogeneous group of patients with stage IV colorectal cancer, among them 32 patients with resectable liver only disease. Liver resection was ultimately performed in 19 patients. Median overall survival in the entire group was 52.9 months.

Reddy et al. (2009) published a multi-institutional study of patients undergoing surgery for initially resectable, synchronous colorectal liver metastasis. A variety of treatment regimens were used, including pre-operative chemotherapy, post-operative chemotherapy, pre- and post-operative treatment, and no chemotherapy. This study found post-operative treatment for six months or longer was associated with improved overall survival in the synchronous liver metastases setting. The heterogeneity of the treatment regimens in terms of timing relative to surgery, duration of therapy, and drugs used makes this analysis difficult to interpret. 
A summary of randomized and observational studies of neoadjuvant chemotherapy was recently published (Chua et al., 2010). With a heterogeneous group of chemotherapy protocols and patients, they estimated an objective response rate of $64 \%$ (range $44-100 \%$ ) and a median overall survival of 46 months (range 20-67 months).

Alternative approaches to neoadjuvant chemotherapy are available. Portier et al. (1996) studied chemotherapy in the adjuvant setting with positive results. They randomized 173 patients to surgery alone versus surgery with adjuvant 5-FU/leucovorin for six months. The 5 year disease-free survival was $26.7 \%$ for the surgery alone arm and $33.5 \%$ for the combined treatment. Hepatic artery infusional chemotherapy has been advocated by some groups as well. Kemeny et al. (1999) randomized 156 patients undergoing liver resection to post-operative systemic 5-FU based chemotherapy versus 5-FU-based hepatic artery infusional chemotherapy along with systemic chemotherapy. The median survival was 59.3 months in the systemic arm and 72.2 months in the combined arm. Two other trials have found similar results (Lygidakis et al., 2001; Kemeny et al., 2002). Despite promising results, this technique has not gained popularity. The technical difficulty and expertise needed to perform the procedure safely has limited its use to a few highly specialized cancer centres, and would pose difficulty in expanding its use to the extraordinary numbers of patients with colorectal cancer.

\section{Special problems related to neoadjuvant chemotherapy for colorectal liver metastases}

\subsection{Hepatotoxicity}

As the administration of neoadjuvant chemotherapy has become more popular, reports have emerged that clearly demonstrate associated hepatotoxicity, which may adversely affect operative outcomes. The type of hepatic injury depends on the agents administered, while the degree of hepatotoxicity is related to duration of therapy, as well as the chemotherapeutic agents used.

Steatosis was one of the first lesions observed in association with chemotherapy. In a phase II clinical trial where irinotecan-based chemotherapy was administered prior to surgery, we observed that $66 \%$ of patients had hepatic steatosis (Bathe et al., 2009). Others have observed lower rates of steatosis, ranging from $9-30 \%$ (Vauthey et al., 2006). This large range may be due to differences in definitions or severity of steatosis, as well as to population-specific factors such as incidence of diabetes and obesity. Vauthey et al. (2006) reported that no specific chemotherapy regimen was particularly associated with steatosis. However, steatohepatitis, which involves a monomorphic and neutrophilic inflammatory response in addition to steatosis, occurs in a minority of individuals, and it is particularly associated with exposure to irinotecan containing regimens $-20.2 \%$ vs. $4.2 \%$ with no chemotherapy (Vauthey et al., 2006).

Vascular changes including hepatic sinusoidal dilatation, peliosis, hemorrhagic centrilobular necrosis and regenerative nodular hyperplasia have also been observed. These lesions are particularly common in individuals who have received oxaliplatin-based regimens (Aloia et al., 2006b; Kandutsch et al., 2008; Karoui et al., 2006; Vauthey et al., 2006). Sinusoidal congestion and dilatation is present in $18-23 \%$ of individuals who have had oxaliplatin (Aloia et al., 2006b; Vauthey et al., 2006; Wicherts et al., 2011a). Regenerative nodules appear in individuals who have had a prolonged exposure to chemotherapy, and they appear to represent an end-stage vascular injury (Aloia et al., 2006b; Wicherts et al., 2011a). 
The effects of each of these lesions on liver function and clinical outcomes following liver resection vary. Steatosis has been associated with an increase in postoperative morbidity although mortality rates do not appear to be adversely affected (Belghiti et al., 1998; Kooby et al., 2003). Steatohepatitis is clearly associated with increased mortality. In the series described by Vauthey and colleagues, steatohepatitis was associated with a 90-day mortality rate of $14.7 \%$, whereas the mortality was only $1.6 \%$ in individuals without steatohepatitis (2006). The impact of sinusoidal dilatation and other vascular injuries from chemotherapy on operative outcomes is not clear. In a number of series, sinusoidal dilatation was not associated with increased morbidity and mortality following liver resection (Kishi et al., 2010; Nordlinger et al., 2008; Kandutsch et al., 2008; Vauthey et al., 2006). However, the more severe vascular lesions, such as hemorrhagic centrilobular necrosis and regenerative nodular hyperplasia, may be associated with increased transfusion requirements and liver dysfunction (Aloia et al., 2006b; Wicherts et al., 2011a). The influence of chemotherapy on operative morbidity is proportional to the duration of neoadjuvant chemotherapy (Aloia et al., 2006b; Karoui et al., 2006; Kishi et al., 2010). This has led to a general recommendation to limit the degree of exposure to chemotherapy in the preoperative phase to a period of two to three months, if possible. In addition, lower morbidity rates have been reported when liver resection is performed more than 4 weeks after stopping chemotherapy (Welsh et al., 2007). There is evidence that some of the biological agents modify the degree of hepatic injury induced by cytotoxic agents. In one report, the prevalence of sinusoidal injury and fibrosis was lower in patients who received cetuximab, and the prevalence of steatohepatitis was lower in patients who received bevacizumab (Pessaux et al., 2010). The addition of bevacizumab or cetuximab to neoadjuvant chemotherapy did not appear to increase the morbidity rates after hepatectomy, and was not associated with any additional histopathologic evidence of hepatic injury. In individuals exposed to 5-FU and oxaliplatin, bevacizumab appears to diminish the incidence and severity of sinusoidal dilatation (Klinger et al., 2009; Ribero et al., 2007). Bevacizumab does not appear to adversely affect postoperative liver function (Wicherts et al., 2011b), but the effects of cetuximab on liver function require further study.

\subsection{Thromboembolic complications}

Any systemic therapy regimen that increases the risk for thromboembolic complications should be viewed with caution when administered in the preoperative setting. Thromboembolic events that occur preoperatively may delay surgery, and patients on anticoagulants will have an increased risk of bleeding from liver resection.

In our own experience, individuals who had irinotecan-based neoadjuvant chemotherapy had a particularly high risk of thromboembolic complications. Significant thromboembolic events have previously been reported with irinotecan and bolus 5-FU/leucovorin (Pan et al., 2005; Rothenberg et al., 2001). Another study utilizing a similar chemotherapy regimen prior to liver resection did not demonstrate such a high thromboembolic event rate (Pozzo et al., 2004). Therefore it is difficult to determine whether the chemotherapy itself represents a risk factor for thromboembolic complications. A number of contributory risk factors are also present in this patient population in addition to the underlying malignancy. In particular, the insertion of indwelling central venous catheters can be associated with increased risk of thromboembolic complications (Seddighzadeh, Shetty, \& Goldhaber, 2007). Given the spurious nature of reports on thromboembolic complications in irinotecan-containing 
neoadjuvant chemotherapy regimens, it is premature to completely dismiss their role in the management of colorectal liver metastases.

Bevacizumab is also associated with a risk of thromboembolic complications including arterial thrombosis (Kozloff et al., 2010; Schutz et al., 2010). Therefore, caution should be utilized when using bevacizumab containing regimens in the preoperative setting. Having said this, a number of series have been reported in which preoperative bevacizumab was not associated with a particularly high rate of thromboembolic complications, and surgery done more than 8 weeks after the last dose of bevacizumab was considered safe (Gruenberger et al., 2008b; Wicherts et al., 2011b).

\subsection{Planning the liver resection following a significant response to chemotherapy} In this chapter we have already shown that unresectable tumors can be downstaged with chemotherapy to a point where they are rendered resectable. However, the question remains whether it is oncologically appropriate to remove less leiver in the case of liver metastases that have shrunk with chemotherapy. A liver-sparing approach would be adequate if the metastasis shrank in a concentric fashion. However, if intratumoral cell death from chemotherapy had a more random distribution, then doing a liver-sparing resection may result in leaving islands of viable tumor in the space previously occupied by the tumor.

Our group studied the histologic patterns of response to chemotherapy to define whether lesions actually shrank in a centripetal fashion (Ng et al, 2008). Our detailed histopathologic analysis demonstrated that tumor did indeed shrink centripedally. However, there were also regional differences in the degree of chemotherapy-induced cell death and fibrosis, resulting in the appearance of islands of viable tumor outside of the confines of the main tumor. Fortunately, these islands of viable tumor always resided close to the gross residual tumor. These observations provided support to the practice of removing only the residual tumor (and possibly preserving liver parenchyma), although a margin of $>1 \mathrm{~cm}$ might be desirable to avoid leaving behind more peripheral islands of viable tumor.

\subsection{Management of a complete response to chemotherapy}

Management of patients who have sustained a complete response to chemotherapy is also controversial. A series of 15 patients with complete radiographic response to chemotherapy was reported by Elias et al. (2004). All were submitted to surgery. In four patients, the lesions could be found at laparotomy, and were therefore resected. In the other 11 patients, the site of liver metastases could not be found at the time of laparotomy and were therefore left in situ. Three of these lesions eventually recurred within a median follow-up of 31.3 months. Benoist and colleagues reported another series of 66 patients with complete disappearance of metastases on CT. Thirty-one patients were observed. Within a year, 23 of these lesions reappeared on CT scan. Of the patients who went for surgery, 20 had macroscopically visible tumor at surgery, 15 had invisible metastases that were resected, and viable tumor cells were seen in 12 of the final pathologic specimens (Benoist et al., 2006). These observations suggest that, in the majority of individuals who have experienced a radiographic complete response to chemotherapy, residual tumor is present. Therefore, there is a rationale to remove all segments of liver in which tumor had resided prior to chemotherapy. Alternatively, patients can be treated expectantly with extremely close follow-up, and ablative treatments can be administered as soon as tumor recurs. 


\subsection{Response as a prognostic marker}

One rationale for neoadjuvant chemotherapy is that it is utilized as a means of selecting patients for resection. In particular, if extrahepatic disease appears during preoperative chemotherapy, then it is not likely that the patient will benefit from hepatic metastasectomy.

Clinical management is not as well defined in patients who experience disease progression while on chemotherapy yet who still have resectable disease confined to the liver. Most data suggest that progression on chemotherapy is associated with a worse prognosis. A large retrospective series reported by Adam and coworkers demonstrated that patients who progressed on chemotherapy prior to liver resection had a 5-year overall survival and diseasefree survival of only $8 \%$ and $3 \%$, respectively (Adam et al., 2004). Similarly, Gruenberger's group reported a median recurrence-free survival of 24.7 months in patients who had a response to chemotherapy, 8.2 months in patients who had stable disease, and only 3.0 months in patients who had progressive disease (Gruenberger et al., 2008a). Others have also demonstrated the prognostic value of response to chemotherapy (Chan et al., 2010; Small et al., 2009). These observations have prompted reflection on whether individuals who have progressed on chemotherapy should be considered candidates for liver resection. On the other hand, some have observed that response to chemotherapy is not prognostic in certain circumstances, such as in synchronous metastases (Gallagher et al., 2009). Moreover, it is not clear whether resection could still provide some clinical advantage in those patients with progression. More research is required to determine the best treatment algorithm for patients who have progressed on chemotherapy yet still have technically resectable disease.

\subsection{The need for a working multidisciplinary tumor conference}

If neoadjuvant chemotherapy is to be considered in the management of colorectal liver metastases, then a coordinated and well-functioning multidisciplinary group is essential. It begins with review of imaging by a radiologist with specialty in the area. In consultation with the surgical team, a decision on resectability should be made from initial imaging. This stratifies the patient into: unresectable/pallative treatment; unresectable but suitable for chemotherapy in an attempt at conversion to resectable status; and resectable at presentation. With this information, the medical oncologist is given clear goals for treatment and an appropriate systemic regimen is chosen. It is important that the medical oncologist understands the concerns of the surgeon with respect to the potential hepatotoxicity of any chemotherapy, and the need to limit the course of treatment to only that which is necessary in the neoadjuvant setting. Administration of drugs such as bevacizumab in the perioperative period is also concerning and further highlights the need to coordinate the timing of chemotherapy and surgery. The surgeon should have a role in ongoing monitoring of patients undergoing a "conversion to resectable" approach in order to decide when the patient has reached a resectable state. The role of an experienced liver surgeon, as well as medical oncologist and others, in the delivery of care cannot be overemphasized. This approach to care has been endorsed by the National Comprehensive Cancer Network and others (NCCN, 2011; Vickers et al., 2010).

\section{Future considerations}

The administration of chemotherapy prior to resection of liver metastases is gaining popularity. There are a number advantages to this approach but there are also some disadvantages, as we have outlined in this article. Trials will be required, trials will be 
required that compare outcomes related to preoperative or perioperative chemotherapy versus postoperative chemotherapy. The design of these trials will be particularly important and will require some forethought. For example, there are some agents, such as bevacizumab and irinotecan, that are unlikely to be successful in an adjuvant setting given results from adjuvant trials in the non-metastatic setting (Saltz et al., 2007; Allegra et al., 2011). More research is required to understand the underlying cause of hepatotoxicity associated with certain chemotherapy agents. Understanding the mechanisms of hepatotoxicity may aid in developing strategies to reduce it, and ultimately enhance the safety of liver resection following chemotherapy. As biological or targeted therapies become more frequently utilized, it may be that current criteria for measuring response (Response Evaluation Criteria In Solid Tumors; RECIST) are insufficient to determine whether there is a benefit to any chemotherapy. This is due to the phenomenon that many of these agents induce more of a cytostatic rather than cytocidal response. Therefore, new methods of determining biological response (including the use of biomarkers and metabolic measures such as PET) will have to be investigated when gauging response. Eventually biomarkers will be developed to predict the likelihood of response to a particular chemotherapy and the identification of such biomarkers would result in truly personalized cancer care. Furthermore, prognostic biomarkers would help to select patients who would most likely benefit from surgery. Ultimately a combination of predictive and prognostic biomarkers would be very useful for this field and will constitute an important part of decision-making in the future.

\section{References}

Abdalla, E.K., Adam, R., Bilchik, A.J., Jaeck, D., Vauthey, J.N., \& Mahvi, D. (2006). Improving resectability of hepatic colorectal metastases: expert consensus statement. Annals of Surgical Oncology, Vol. 13, No. 10 (October 2006), pp.1271-80, ISSN 1534-4681.

Abdalla, E. K., Vauthey, J.-N., Ellis, L. M., Ellis, V., Pollock, R., Broglio, K.R., Hess, K. \& Curley, S.A. (2004). Recurrence and outcomes following hepatic resection, radiofrequency ablation, and combined resection/ablation for colorectal liver metastases. Annals of Surgery Vol. 239, No. 6 (June 2004), pp.818-827, ISSN 0003-4932.

Adam, R., Avisar, E., Ariche, A., Giachetti, S., Azoulay, D., Castaing, D., Kunstlinger, F., Levi, F. \& Bismuth, F. (2001). Five-year survival following hepatic resection after neoadjuvant therapy for nonresectable colorectal. Annals of Surgical Oncology, Vol. 8, No. 4(January 2001), pp. 347-353, ISSN 1534-4681.

Adam, R., Delvart, V., Pascal, G., Valeanu, A., Castaing, D., Azoulay, D., Giacchetti, S., Paule, B., Kunstlinger, F., Ghemard, O., Levi, F., Bismuth, H. (2004a). Rescue surgery for unresectable colorectal liver metastases downstaged by chemotherapy A model to predict survival. Annals of Surgery, Vol.240, No. 2 (August 2004), pp.242-256, ISSN 0003-4932.

Adam, R., Pascal, G., Castaing, D., Azoulay, D., Delvart, V., Paule, B., Levi, F. \& Bismuth, H. (2004). Tumor progression while on chemotherapy: a contraindication to liver resection for multiple colorectal metastases? Annals of Surgery, Vol. 240, No. 6 (December 2004b), pp. 1052-1064, ISSN 0003-4932.

Adam, R., de Haas, R.J., Wicherts, D., Vibert, E., Salloum, C., Azoulay, D. \& Castaing, D. (2011). Concomitant extrahepatic disease in patients with colorectal liver 
metastases: when is there a place for surgery? Annals of Surgery, Vol. 253, No. 2 (February 2011), pp.349-359, ISSN 0003-4932.

Allegra, C.J., Yothers, G., O'Connell, M.J., Sharif, S., Petrelli, N.J., Colangelo, L.H., Atkins, J.N., Seay, T.E., Fehrenbacher, L., Goldberg, R.M., O'Reilly, S., Chu L., Azar, C.A., Lopa, S. \& Wolmark, N. (2011). Phase III trial assessing bevacizumab in stages II and III carcinoma of the colon: Results of NASBP protocol C-08. Journal of Clinical Oncology, Vol. 29, No. 1 (January 2011), pp. 11-16, ISSN 1527-7755.

Aloia, T.A., Vauthey, J.N., Loyer, E.M., Ribero, D., Pawlik, T.M., Wei, S.H., Curley, S.A., Zorzia, D. \& Abdalla, E.K. (2006a). Solitary colorectal liver metastasis: resection determines outcome. Archives of Surgery, Vol. 141, No. 5 (May 2006), pp.460-466, ISSN 0004-0010.

Aloia, T., Sebagh, M., Plasse, M., Karam, V., Levi, F., Giacchetti, S., et al. (2006b). Liver histology and surgical outcomes after preoperative chemotherapy with fluorouracil plus oxaliplatin in colorectal cancer liver metastases. Journal of Clinical Oncology, Vol. 24, No. 31(November 2006), pp. 4983-4990, ISSN 1527-7755.

Bathe, O.F., Ernst, S., Sutherland, F.R., Dixon, E., Butts, C., Bigam, D., Holland, D., Porter, GA., Koppel, J. \& Dowden, S. (2009). A phase II experience with neodjuvant irinotecan (CPT-11), 5-fluorouracil (5-FU) and leucovorin (LV) for colorectal liver metastases. BMC Cancer, Vol. 9 (May 2009), pp. 156, ISSN 1471-2407.

Behrns, K.E., Tsiotos, G.G., DeSouza, N.F., Krishna, M.K., Ludwig, J., Nagorney, D.M. (1998). Hepatic steatosis as a potential risk factor for major hepatic resection. Journal of Gastrointestinal Surgery, Vol 2, No. 3 (May-June 1998), pp. 292-8, ISSN 1873-4626.

Bajetta, E., Di Bartolomeo, M., Mariani, L., Cassata, A., Artale, S., Frustaci, S., Pinotti, G., Bonetti, A., Carreca, I., Biasco, G., Bonaglia, L., Marini, G., Iannelli, A., Cortinovis, D., Ferrario, E., Beretta, E., Lambiase, A. \& Buzzoni, R. (2004). Randomized multicenter Phase II trial of two different schedules of irinotecan combined with capecitabine as first-line treatment in metastatic colorectal carcinoma. Cancer, Vol. 100, No. 2 (January 2004), pp. 279-287, ISSN 1097-0142.

Benoist, S., Brouquet, A., Penna, C., Julié, C., El Hajjam, M., Chagnon, S., Mitry, E., Rougier, P. \& Nordlinger, B. (2006). Complete response of colorectal liver metastases after chemotherapy: Does it mean cure? Journal of Clinical Oncology, Vol., 24, No. 24 (August 2006), pp. 3939-3945, ISSN 1527-7755.

Bismuth, H., Adam, R., Levi, F., Farabos, C., Waechter, F., Castaing, D., Majno, P., \& Engerran, L. (1996). Resection of nonresectable liver metastases from colorectal cancer after neoadjuvant chemotherapy. Annals of Surgery, Vol. 224, No. 4 (October 1996), pp. 509-522, ISSN 0003-4932.

Brouquet, A., Mortenson, M.M., Vauthey, J.N., Rodriguez-Bigas, M.A., Overman, M.J., Chang, G.J., Kopetz, S., Garrett, C., Curley, S.A. \& Abdalla, E.K. (2010). Surgical strategies for synchronous colorectal liver metastases in 156 consecutive patients: classic, combined or reverse strategy? Journal of the American College of Surgeons, Vol. 210, No. 6 (June 2010), pp.934-41, ISSN 1879-1190.

Carpizo, D.R., \& D'Angelica, M. (2009). Liver resection for metastatic colorectal cancer in the presence of extrahepatic disease. The Lancet Oncology, Vol. 10, No. 8(August 2009), pp.801-809, ISSN 1474-5488.

Cassidy, J., Tabernero, J., Twelves, C., Brunet, R., Butts, C., Conroy, T., Debraud, F., Figer, A., Grossmann, J., Sawada, N., Schoffski, P., Sobrero, A., Van Cutsem, E. \& Diaz- 
Rubio, E. (2004). XELOX (capecitabine plus oxaliplatin): active first-line therapy for patients with metastatic colorectal cancer. Journal of Clinical Oncology, Vol. 22, No. 11 (June 2004), pp. 2084-2091, ISSN 1527-7755.

Cellini, C., Hunt, S.R., Fleshman, J.W., Birnbaum, E.H., Bierhals, A.J., \& Mutch, M.G. (2010). Stage IV rectal cancer with liver metastases: is there a benefit to resection of the primary tumor? World Journal of Surgery, Vol. 34, No. 5 (May 2010), pp.1102-1108, ISSN 1432-2323.

Chan, G., Hassanain, M., Chaudhury, P., Vrochides, D., Neville, A., Cesari, M., Kavan, P., Marcus, V. \& Metrakos P. (2010). Pathological response grade of colorectal liver metastases treated with neoadjuvant chemotherapy. HPB (Oxford), Vol. 12, No. 4 (May 2010), pp. 277-284, ISSN:1477-2574.

Charnsangavej, C., Clary, B., Fong, Y., Grothey, A., Pawlik, T.M., \& Choti, M.A. (2006). Selection of patients for resection of hepatic colorectal metastases: expert consensus statement. Annals of Surgical Oncology, Vol.13, No.10 (October 2006), pp.1261-1268, ISSN 1534-4681.

Choti, M.A., Sitzmann, J.V., Tiburi, M.F., Sumetchotimetha, W., Rangsin, R., Schulick, R D., Lillemoe, K.D., Yeo, C.J. \& Cameron, J.L. (2002). Trends in long-term survival following liver resection for hepatic colorectal metastases. Annals of Surgery Vol. 235, No. 6 (June 2002), pp.759-766, ISSN 0003-4932.

Chua, T.C., Saxena, A., Liauw, W., Kokandi, A. \& Morris, D.L. (2010). Systematic review of randomized and nonrandomized trials of the clinical response and outcomes of neoadjuvant systemic chemotherapy for resectable colorectal liver metastases. Annals of Surgical Oncology, Vol. 17, No. 2 (February 2010), pp. 492-501, ISSN 1534-4681.

Chun, Y.S., Vauthey, J.N., Ribero, D., Donadon, M., Mullen, J.T., Eng, C., Madoff, D.C., Chang, D.Z., Ho, L., Kopetz, S., Wei, S.H., Curley, S.A. \& Abdalla, E.K. (2007). Systemic chemotherapy and two-stage hepatectomy for extensive bilateral colorectal liver metastases: perioperative safety and survival. Journal of Gastrointestinal Surgery, Vol.11, No.11 (November 2007), pp.1498-1504, ISSN 1873-4626.

Compton, C., Hawk, E., Grochow, L., et al. (2008). Chapter 81 - Colon Cancer, In: Abeloff's Clinical Oncology, 4th ed. Abeloff, M.D., Armitage, J.O., Niederhuber, J.E., Kastan, M.B., \& McKenna, W.G. pp. 1477-1525. Elsevier, ISBN 978-0-443-06694-8, Philadelphia.

Cook, A.D., Single, R., \& McCahill, L.E. (2005). Surgical resection of primary tumors in patients who present with stage IV colorectal cancer: an analysis of surveillance, epidemiology, and end results data, 1988 to 2000. Annals of Surgical Oncology, Vol.12, No.8 (August 2005), pp.637-645, ISSN 1534-4681.

Cummings, L.C., Payes, J.D., \& Cooper, G.S. (2007). Survival after hepatic resection in metastatic colorectal cancer: a population-based study. Cancer, Vol. 109, No. 4 (February 2007), pp.718-726, ISSN 1097-0142.

Delaunoit, T., Alberts, S.R., Sargent, D.J., Green, E., Goldberg, R.M., Krook, J., Fuchs, C., Ramanathan, R.K., Williamson, S.K., Morton, R.F. \& Findlay, B.P. (2005). Chemotherapy permits resection of metastatic colorectal cancer: Experience from Intergroup N9741. Annals of Oncology, Vol. 16, No. 3 (March 2005), pp. 425-429, ISSN 1569-8041.

De Gramont, A., Figer, A., Seymour, M., Homerin, M., Hmissi, A., Cassidy, J., Boni, C., Cortes-Funes, H., Cervantes, A., Freyer, G., Papamichael, D., Le Bail, N., Louvet, C., 
Hendler, D., de Braud, F., Wilson, C., Morvan ,F. \& Bonetti A. (2000). Leucovorin and fluorouracil with or without oxaliplatin as first-line treatment in advanced colorectal cancer. Journal of Clinical Oncology, Vol. 18, No. 16 (August 2000), pp. 2938-2947, ISSN 1527-7755.

Douillard, J. Y., Siena, S., Cassidy, J., Tabernero, J., Burkes, R., Barugel, M., Humblet, Y., Bodoky, G., Cunningham, D., Jassem, J., Rivera, F., Kocákova, I., Ruff, P., BłasińskaMorawiec, M., Šmakal, M., Canon, J.L., Rother, M., Oliner, K.S., Wolf, M. \& Gansert J. (2010). Randomized, phase III trial of panitumumab with infusional fluorouracil, leucovorin, and oxaliplatin (FOLFOX4) versus FOLFOX4 alone as first-line treatment in patients with previously untreated metastatic colorectal cancer: the PRIME study. Journal of Clinical Oncology, Vol. 28, No. 31 (November 2010), pp.4697-4705, ISSN 1527-7755.

Elias, D., Youssef, O., Sideris, L., Dromain, C., Baton, O., Boige, V., \& Ducreux, M. (2004). Evolution of missing colorectal liver metastases following inductive chemotherapy and hepatectomy. Journal of Surgical Oncology, Vol. 86, No. 1 (April 2004), pp. 4-9, ISSN 1096-9098.

Falcone, A., Ricci, S., Brunetti, I., Pfanner, E., Allegrini, G., Barbara, C., Crino, L., Benedetti, G., Evangelista, W., Fanchini, L., Cortesi, E., Picone, V., Vitello, S., Chiara, S., Granetto, C., Porcile, G., Fioretto, L., Orlandini, C., Andreuccetti, M. \& Masi, G. (2007). Phase III trial of infusional fluorouracil, leucovorin, oxaliplatin, and irinotecan (FOLFOXIRI) compared with infusional fluorouracil, leucovorin, and irinotecan (FOLFIRI) as first-line treatment for metastatic colorectal cancer: the Gruppo Oncologico Nord Ovest. Journal of Clinical Oncology, Vol. 25, No. 13 (May 2007), pp. 1670-1676, ISSN 1527-7755.

Fernandez, F.G., Drebin, J.A., Linehan, D.C., Dehdashti, F., Siegel, B.A., \& Strasberg, S.M. (2004). Five-year survival after resection of hepatic metastases from colorectal cancer in patients screened by positron emission tomography with F-18 fluorodeoxyglucose (FDG-PET). Annals of Surgery, Vol. 240, No. 3 (Spetmber 2004), pp.438-450, ISSN 0003-4932.

Figueras, J., Valls, C., Rafecas, A., Fabregat, J., Ramos, E., \& Jaurrieta, E. (2001). Resection rate and effect of postoperative chemotherapy on survival after surgery for colorectal liver metastases. British Journal of Surgery, Vol. 88, No. 7 (July 2001), pp. 980-985, ISSN 0007-1323.

Figueras, J., Torras, J., Valls, C., Llado, L., Ramos, E., Marti-Ragué, J., Serrano, T. \& Fabregat, J. (2007). Surgical resection of colorectal liver metastases in patients with expanded indications: a single-center experience with 501 patients. Diseases of the Colon and Rectum, Vol. 50, No. 4 (April 2007), pp.478-488, ISSN 0012-3706.

Folprecht, G., Gruenberger, T., Bechstein, W.O., Raab, H.R., Lordick, F., Hartmann, J.T., Lang, H., Frilling, A., Stoehlmacher, J. \& Weitz, J. (2010). Tumour response and secondary resectability of colorectal liver metastases following neoadjuvant chemotherapy with cetuximab: the CELIM randomised phase 2 trial. The Lancet Oncology, Vol. 11, No. 1 (January 2010), pp.38-47, ISSN 1474-5488.

Fong, Y., Cohen, A. M., Fortner, J. G., Enker, W. E., Turnbull, A. D., Coit, D. G., Marrero, A.M., Prasad, M., Blumgart, L.H. \& Brennan, M.F. (1997). Liver resection for colorectal metastases. Journal of Clinical Oncology, Vol. 15, No. 3 (March 1997), pp.938-946, ISSN 1527-7755. 
Gallagher, D. J., Zheng, J., Capanu, M., Haviland, D., Paty, P., Dematteo, R. P., D'Angelica, M., Fong, Y., Jarnagin, W.R., Allen, P.J. \& Kemeny, N. (2009). Response to neoadjuvant chemotherapy does not predict overall survival for patients with synchronous colorectal hepatic metastases. Annals of Surgical Oncology, Vol. 16, No. 7 (July 2009), pp. 1844-1851, ISSN 1534-4681.

Giacchetti, S., Itzhaki, M., Gruia, G., Adam, R., Zidani, R., Kunstlinger, F., Brienza, S., Alafaci, E., Bertheault-Cvitkovic, F., Jasmin, C., Reynes, M., Bismuth, H., Misset, J.L. \& Levi, F. (1999). Long-term survival of patients with unresectable colorectal cancer liver metastases following infusional chemotherapy with 5-fluorouracil, leucovorin, oxaliplatin and surgery. Annals of Oncology, Vol. 10, No. 6 (June 1999), pp. 663-669, ISSN 1569-8041.

Giacchetti, S., Perpoint, B., Zidani, R., Le Bail, N., Faggiuolo, R., Focan, C., Chollet, P., Llory, J.F., Letourneau, Y., Coudert, B., Bertheaut-Cvitkovic, F., Larregain-Fournier, D., Le Rol, A., Walter, S., Adam, R., Misset, J.L. \& Levi, F. (2000). Phase III multicenter randomized trial of oxaliplatin added to chronomodulated fluorouracil-leucovorin as first-line treatment of metastatic colorectal cancer. Journal of Clinical Oncology, Vol. 18, No. 1 (January 2000), pp. 136-147, ISSN 1527-7755.

Gruenberger, B., Scheithauer, W., Punzengruber, R., Zielinski, C., Tamandl, D., \& Gruenberger, T. (2008a). Importance of response to neoadjuvant chemotherapy in potentially curable colorectal cancer liver metastases. BMC Cancer, Vol. 8 (April 2008), pp. 120, ISSN 1471-2407.

Gruenberger, B., Tamandl, D., Schueller, J., Scheithauer, W., Zielinski, C., Herbst, F. \& Gruenberger, T.. (2008b). Bevacizumab, capecitabine, and oxaliplatin as neoadjuvant therapy for patients with potentially curable metastatic colorectal cancer. Journal of Clinical Oncology, Vol. 26, No. 11 (April 2008), pp. 1830-1835, ISSN 1527-7755.

de Haas, R.J., Adam, R., Wicherts, D.A., Azoulay, D., Bismuth, H., Vibert, E., Salloum, C., Perdigao, F., Benkabbou, A. \& Castaing, D. (2010). Comparison of simultaneous or delayed liver surgery for limited synchronous colorectal metastases. British Journal of Surgery, Vol. 97, No. 8 (August 2010), pp.1279-1289, ISSN 0007-1323.

Kandutsch, S., Klinger, M., Hacker, S., Wrba, F., Gruenberger, B., \& Gruenberger, T. (2008). Patterns of hepatotoxicity after chemotherapy for colorectal cancer liver metastases. European Journal of Surgical Oncology, Vol. 34, No. 11 (November 2008), pp. 12311236, ISSN 0748-7983.

Karapetis, C. S., Khambata-Ford, S., Jonker, D. J., O'Callaghan, C. J., Tu, D., Tebbutt, N. C., Simes, R.J., Chalchal, H., Shapiro, J.D., Robitaille, S., Price, T.J., Shepherd, L., Au, H.J., Langer, C., Moore, M.J. \& Zalcberg, J.R. (2008). K-ras mutations and benefit from cetuximab in advanced colorectal cancer. New England Journal of Medicine, Vol. 359, No. 17 (October 2008), pp. 1757-1765, ISSN 0028-4793.

Karoui, M., Penna, C., Amin-Hashem, M., Mitry, E., Benoist, S., Franc, B., Rougier, P. \& Nordlinger, B. (2006). Influence of preoperative chemotherapy on the risk of major hepatectomy for colorectal liver metastases. Annals of Surg, Vol. 243, No. 1 (January 2006), pp. 1-7, ISSN 0003-4932.

Kemeny, N., Huang, Y., Cohen, A.M., Shi, W., Conti, J.A., Brennan, M.F., Bertino, J.R., Turnbull, A.D., Sullivan, D., Stockman, J., Blumgart, L.H. \& Fong, Y. (1999). Hepatic arterial infusion of chemotherapy after resection of hepatic metastases from 
colorectal cancer. New England Journal of Medicine, Vol. 341, No. 27 (December 1999), pp. 2039 - 2048, ISSN 0028-4793.

Kemeny, M.M., Adak, S., Gray, B., Macdonald, J.S., Smith, T., Lipsitz, S., Sigurdson, E.R., O'Dwyer, P.J. \& Benson, A.B.3rd. (2002). Combined-modality treatment for resectable metastatic colorectal carcinoma to the liver: Surgical resection of hepatic metastases in combination with continuous infusion of chemotherapy-An intergroup study. Journal of Clinical Oncology, Vol. 20, No. 6 (March 2002), pp.1499 1505, ISSN 1527-7755.

Kishi, Y., Zorzi, D., Contreras, C. M., Maru, D. M., Kopetz, S., Ribero, D., Motta, M., Ravarino, N., Risio, M., Curley, S.A., Abdalla, E.K., Capussotti, L. \& Vauthey, J.N. (2010). Extended preoperative chemotherapy does not improve pathologic response and increases postoperative liver insufficiency after hepatic resection for colorectal liver metastases. Annals of Surgical Oncology, Vol. 17, No. 11 (November 2010), pp. 2870-2876, ISSN 1534-4681.

Klinger, M., Eipeldauer, S., Hacker, S., Herberger, B., Tamandl, D., Dorfmeister, M., Koelblinger, C., Gruenberger, B. \& Gruenberger, T. (2009). Bevacizumab protects against sinusoidal obstruction syndrome and does not increase response rate in neoadjuvant XELOX/FOLFOX therapy of colorectal cancer liver metastases. European Journal of Surgical Oncology, Vol. 35, No. 5 (May 2009), pp. 515-520, ISSN 0748-7983.

Kohne, C.H., van Cutsem, E., Wils, J., Bokemeyer, C., El-Serafi, M., Lutz, M.P., Lorenz, M., Reichardt, P., Ruckle-Lanz, H., Frickhofen, N., Fuchs, R., Mergenthaler, H.G., Langenbuch, T., Vanhoefer, U., Rougier, P., Voigtmann, R., Muller, L., Genicot, B., Anak, O. \& Nordlinger, B. (2005). Phase III study of weekly high-dose infusional fluorouracil plus folinic acid with or without irinotecan in patients with metastatic colorectal cancer: European Organisation for Research and Treatment of Cancer Gastrointestinal Group Study 40986. Journal of Clinical Oncology, Vol. 23, No. 22 (August 2005), pp. 4856-4865, ISSN 1527-7755.

Kooby, D., Fong, Y., Suriawinata, A., Gonen, M., Allen, P., Klimstra, D., DeMatteo, R.P., D'Angelica, M., Blumgart, L.H. \& Jarnagin, W.R. (2003). Impact of steatosis on perioperative outcome following hepatic resection. Journal of Gastrointestinal Surgery, Vol. 7, No. 8 (December 2003), pp. 1034-1044, ISSN 1873-4626.

Kozloff, M. F., Berlin, J., Flynn, P. J., Kabbinavar, F., Ashby, M., Dong, W., Sing, A.P. \& Grothey, A. (2010). Clinical outcomes in elderly patients with metastatic colorectal cancer receiving bevacizumab and chemotherapy: results from the BRiTE observational cohort study. Oncology, Vol. 78, No. 5-6 (November 2010), pp. 329339, ISSN 0030-2414.

Levi, F., Zidani, R., Brienza, S., Dogliotti, L., Perpoint, B., Rotarski, M., Letourneau, Y., Llory, J.F., Chollet, P., Le Rol, A. \& Focan, C. (1999). A multicenter evaluation of intensified, ambulatory, chronomodulated chemotherapy with oxaliplatin, 5fluorouracil, and leucovorin as initial treatment of patients with metastatic colorectal carcinoma. International Organization for Cancer Chronotherapy. Cancer, Vol. 85, No. 12 (June 1999), pp. 2532-2540, ISSN 1097-0142.

Lyass, S., Zamir, G., Matot, I., Goitein, D., Eid, A., \& Jurim, O. (2001). Combined colon and hepatic resection for synchronous colorectal liver metastases. Journal of Surgical Oncology, Vol. 78, No. 1 (September 2001), pp.17-21, ISSN 1096-9098. 
Lygidakis, N.J., Sgourakis, G., Vlachos, L., Raptis, S., Safioleas, M., Boura, P., Kountouras, J. \& Alamani, M. (2001). Metastatic liver disease of colorectal origin: The value of locoregional immunochemotherapy combined with systemic chemotherapy following liver resection. Results of a prospective randomized study. Hepatogastroenterology, Vol. 48, No. 48 (November/December 2001), pp. 1685-1691, ISSN 0172-6390.

Martin, R.C.G., Augenstein, V., Reuter, N.P., Scoggins, C.R., \& McMasters, K.M. (2009). Simultaneous versus staged resection for synchronous colorectal cancer liver metastases. Journal of the American College of Surgeons, Vol. 208, No. 5 (May 2009), pp.842-850, ISSN 1879-1190.

Masi, G., Cupini, S., Marcucci, L., Cerri, E., Loupakis, F., Allegrini, G., Brunetti, I.M., Pfanner, E., Viti, M., Goletti, O., Filipponi, F. \& Falcone, A. (2006). Treatment with 5-fluorouracil/folinic acid, oxaliplatin, and irinotecan enables surgical resection of metastases in patients with initially unresectable metastatic colorectal cancer. Annals of Surgical Oncology, Vol. 13, No. 1 (January 2006), pp. 58-65, ISSN 1534-4681.

Masi, G., Loupakis, F., Pollina, L., Vasile, E., Cupini, S., Ricci, S., Brunetti, I.M., Ferraldeschi, R., Naso, G., Filiponni, F., Pietrabissa, A., Goletti, O., Baldi, G., Fornaro, L, Andreuccetti, M. \& Falcone, A. (2009). Long-term outcome of initially unresectable metastatic colorectal cancer patients treated with 5-fluorouracil/leucovorin, oxaliplatin, and irinotecan (FOLFOXIRI) followed by radical surgery of metastases. Annals of Surgery, Vol. 249, No. 3 (Marhc 2009), pp.420-425, ISSN 0003-4932.

Moehler, M., Hoffmann, T., Zanke, C., Hohl, H., Burg, H., Ehscheid, P., Schwindt, P., Adami, B., Schroeder, M., Klein, O., Baldus, M., Galle, P.R. \& Heike, M. (2003). Safety and efficacy of outpatient treatment with CPT-11 plus bolus folinic acid/5-fluorouracil as first-line chemotherapy for metastatic colorectal cancer. Anticancer Drugs, Vol. 14, No. 1 (January 2003), pp. 79-85, ISSN 1473-5741.

National Comprehensive Cancer Network (2011). Colon Cancer. In: NCCN Clinical Practice Guidelines in Oncology. Accessed April 6, 2011. Available from: http://www.nccn.org.

Ng, J.K., Urbanski, S.J., Mangat, N., McKay, A., Sutherland, F.R., Dixon, E., Dowden, S., Ernst, S., Bathe, O.F. (2008). Colorectal liver metastasis contract centripetally, with a response to chemotherapy: A histomorphologic study. Cancer, Vol. 115, No. 2 (January 2008), pp. 362-71, ISSN 1097-0142.

Nikfarjam, M., Shereef, S., Kimchi, E.T., Gusani, N.J., Jiang, Y., Avella, D.M., Mahraj, R.P. \& Staveley-O'Carroll, K.F. (2009). Survival outcomes of patients with colorectal liver metastases following hepatic resection or ablation in the era of effective chemotherapy. Annals of Surgical Oncology, Vol. 16, No. 7 (July 2009), pp.1860-1867, ISSN 1534-4681.

Nordlinger, B., Sorbye, H., Glimelius, B., Poston, G.J., Schlag, P.M., Rougier, P., Bechstein, W.O., Primrose, J.N., Walpole, E.T., Finch-Jones, M., Jaeck, D., Mirza, D., Parks, R.W., Collette, L., Praet, M., Bethe, U., Van Cutsem, E., Scheithauer, W. \& Gruenberger, T. (2008). Perioperative chemotherapy with FOLFOX4 and surgery versus surgery alone for respectable liver metastasis from colorectal cancer (EORTC Intergroup trial 40983): a randomised control trial. Lancet, Vol. 371, No. 9617 (March 2008), pp. 1007-1015, ISSN 0140-6736. 
Nordlinger, B., Van Cutsem, E., Gruenberger, T., Glimelius, B., Poston, G., Rougier, P., Sobrero, A., Ychou, M. (2009). Combination of surgery and chemotherapy and the role of targeted agents in the treatment of patients with colorectal liver metastases: Recommendations from an expert panel. Annals of Oncology, Vol. 20, No. 6 (June 2009), pp.985-992, ISSN 1569-8041.

Pan, C. X., Loehrer, P., Seitz, D., Helft, P., Juliar, B., Ansari, R., Pletcher, W., Vinson, J., Cheng, L. \& Sweeney, C. (2005). A phase II trial of irinotecan, 5-fluorouracil and leucovorin combined with celecoxib and glutamine as first-line therapy for advanced colorectal cancer. Oncology, Vol. 69, No. 1 (August 2005), pp. 63-70, ISSN 0030-2414.

Pawlik, T. M., Scoggins, C. R., Zorzi, D., Abdalla, E. K., Andres, A., Eng, C., Curley, S.A., Loyer, E.M., Muratore, A., Mentha, G., Capussotti, L. \& Vauthey, J.N. (2005). Effect of surgical margin status on survival and site of recurrence after hepatic resection for colorectal metastases. Annals of Surgery, Vol. 241, No. 5 (May 2005), pp.715-724, ISSN 0003-4932.

Pessaux, P., Panaro, F., Casnedi, S., Zeca, I., Marzano, E., Bachellier, P., Jaeck, D. \& Chenard, M.P. (2010). Targeted molecular therapies (cetuximab and bevacizumab) do not induce additional hepatotoxicity: preliminary results of a case-control study. European Journal of Surgical Oncology, Vol. 36, No. 6 (June 2010), pp. 575-582, ISSN 0748-7983.

Portier, G., Elias, D., Bouche, O., Rougier, P., Bosset, J.F., Saric, J., Belghiti, J., Piedbois, P., Guimbaud, R., Nordlinger, B., Bugat, R., Lazorthes, F. \& Bedenne, L. (2006). Multicenter randomized trial of adjuvant fluoruracil and folinic acid compared with surgery alone after resection of colorectal liver metastasis: FFCD ACHBTH AURC 9002 trial. Journal of Clinical Oncology, Vol. 24, No.10, (November 2006), pp. 4976-4982, ISSN 1527-7755.

Pozzo, C., Basso, M., Cassano, A., Quirino, M., Schinzari, G., Trigila, N., Vellone, M., Giuliante, F., Nuzzo, G. \& Barone, C. (2004). Neoadjuvant treatment of unresectable liver disease with irinotecan and 5-fluorouracil plus folinic acid in colorectal cancer patients. Annals of Oncology, Vol. 15, No. 6 (June 2004), pp. 933-939, ISSN 1569-8041.

Reddy, S.K., Zorzi, D., Lum, Y.W., Barbas, A.S., Pawlik, T.M., Ribero, D., Abdalla, E.K., Choti, M.A., Kemp, C., Vauthey, J.N., Morse, M.A., White, R.R., Clary, B.M. (2009). Timing of multimodality therapy for resectable synchronous colorectal liver metastases: a retrospective multi-institutional analysis. Annals of Surgical Oncology, Vol 16, No. 7 (July 2009), pp. 1809-1819, ISSN 1534-4681.

Rennes University Hospital. (2009). Evaluation of 2 Resection Strategies of Synchronous Colorectal Cancer Metastases (METASYNC) - NCT00264979. US National Institute of Health. Accessed: April 11, 2001. Available from

http:/ / clinicaltrials.gov/ct2/ show/NCT00264979?term=hepatic+synchronous\&ra $\mathrm{nk}=1$

Ribero, D., Wang, H., Donadon, M., Zorzi, D., Thomas, M. B., Eng, C., Chang, D.Z., Curley, S.A., Abdalla, E.K., Ellis, L.M. \& Vauthey, J.N. (2007). Bevacizumab improves pathologic response and protects against hepatic injury in patients treated with oxaliplatin-based chemotherapy for colorectal liver metastases. Cancer, Vol. 110, No. 12 (December 2007), pp. 2761-2767, ISSN: 1097-0142. 
Rivoire, M., De Cian, F., Meeus, P., Negrier, S., Sebban, H. \& Kaemmerlen, P. (2002). Combination of neoadjuvant chemotherapy with cryotherapy and surgical resection for the treatment of unresectable liver metastases from colorectal carcinoma. Cancer, Vol. 95, No. 11 (December 2002), pp. 2283-2292, ISSN 1097-0142.

Robertson, D.J., Stukel, T.A., Gottlieb, D.J., Sutherland, J.M., \& Fisher, E.S. (2009). Survival after hepatic resection of colorectal cancer metastases: a national experience. Cancer, Vol. 115, No. 4 (February 2009), pp. 752-759, ISSN 1097-0142.

Rothenberg, M.L., Meropol, N J., Poplin, E.A., Van Cutsem, E., \& Wadler, S. (2001). Mortality associated with irinotecan plus bolus fluorouracil/leucovorin: summary findings of an independent panel. Journal of Clinical Oncology, Vol. 19, No. 18 (Septmber 2001), pp. 3801-3807, ISSN 1527-7755.

Ruo, L., Gougoutas, C., Paty, P.B., Guillem, J.G., Cohen, A.M. \& Wong, W.D. (2003). Elective bowel resection for incurable stage IV colorectal cancer: Prognostic variables for asymptomatic patients. Journal of the American College of Surgeons, Vol. 196, No. 5 (May 2003), pp.722-728, ISSN 1879-1190.

Saltz, L. B., Clarke, S., Díaz-Rubio, E., Scheithauer, W., Figer, A., Wong, R., Koski, S., Lichinitser, M., Yang, T.-S., Rivera, F., Couture, F., Sirzen, F. \& Cassidy, J. (2008). Bevacizumab in combination with oxaliplatin-based chemotherapy as first-line therapy in metastatic colorectal cancer: a randomized phase III study. Journal of Clinical Oncology, Vol. 26, No. 12 (May 2008), pp. 2013-2019, ISSN 1527-7755.

Saltz, L.B., Niedzwiecki, D., Hollis, D., Goldberg, R.M., Hantel, A., Thomas, J.P., Fields, A.L., \& Mayer, R.J. (2007). Irinotecan fluorouracil plus leucovorin is not superior to fluorouracil plus leucovorin alone as adjuvant treatment for stage III colon cancer: Results of CALGB 89803. Journal of Clinical Oncology, Vol. 25, No. 23 (August 2007), pp. 3456-3461, ISSN 1527-7755.

Scheele, J. \& Altendorf-Hofmann. A. (1999). Resection of colorectal liver metastases. Langenbeck's Archives of Surgery, Vol. 384, No. 4 (August 1999), pp.313-327, ISSN 1435-2443.

Scheithauer W, Kornek GV, Raderer M, Schüll B, Schmid K, Kovats E, Schneeweiss B, Lang F, Lenauer A, Depisch D. (2003). Randomized multicenter phase II trial of two different schedules of capecitabine plus oxaliplatin as first-line treatment in advanced colorectal cancer. Journal of Clinical Oncology, Vol. 21, No. 7 (April 2003), pp. 1307-1312, ISSN 1527-7755.

Scheer, M.G.W., Sloots, C.E.J., van der Wilt, G.J., \& Ruers, T.J.M. (2008). Management of patients with asymptomatic colorectal cancer and synchronous irresectable metastases. Annals of Oncology, Vol. 19, No. 11 (November 2008), pp.1829-1835, ISSN 1569-8041.

Schutz, F.A., Je, Y., Azzi, G.R., Nguyen, P.L., \& Choueiri, T.K. (2011). Bevacizumab increases the risk of arterial ischemia: a large study in cancer patients with a focus on different subgroup outcomes. Annals of Oncology, Vol. 22, No. 6 (June 2011), pp. 1404-1412, ISSN 1569-8041.

Seddighzadeh, A., Shetty, R., \& Goldhaber, S. Z. (2007). Venous thromboembolism in patients with active cancer. Thrombosis and Haemostasis, Vol. 98, No. 3 (Septmber 2007), pp. 656-661, ISSN 0340-6245.

Small, R. M., Lubezky, N., Shmueli, E., Figer, A., Aderka, D., Nakache, R., Klausner, J.M. \& Ben-Haim, M. (2009). Response to chemotherapy predicts survival following 
resection of hepatic colo-rectal metastases in patients treated with neoadjuvant therapy. Journal of Surgical Oncology, Vol. 99, No. 2 (February 2009), pp. 93-98, ISSN 1096-9098.

Sorbye, H., Glimelius, B., Berglund, A., Fokstuen, T., Tveit, K.M., Braendengen, M., Ogreid, D. \& Dahl, O. (2004). Multicenter phase II study of Nordic fluorouracil and folinic acid bolus schedule combined with oxaliplatin as first-line treatment of metastatic colorectal cancer. Journal of Clinical Oncology, Vol 22., No. 1 (January 2004), pp. 3138, ISSN 1527-7755.

Tabernero, J., Van Cutsem, E., Diaz-Rubio, E., Cervantes, A., Humblet, Y., Andre, T., Van Laethem, J.L., Soulie, P., Casado, E., Verslype, C., Valera, J.S., Tortora, G., Ciardiello, F., Kisker, O. \& de Gramont, A. (2007). Phase II trial of cetuximab in combination with fluorouracil, leucovorin, and oxaliplatin in the first-line treatment of metastatic colorectal cancer. Journal of Clinical Oncology, Vol. 25, No. 33 (November 2007), pp. 5225-5235, ISSN 1527-7755.

Tournigand, C., Andre, T., Achille, E., Lledo, G., Flesh, M., Mery-Mignard, D., Quinaux, E., Couteau, C., Buyse, M., Ganem, G., Landi, B., Colin, P., Louvet, C. \& de Gramont, A. (2004). FOLFIRI followed by FOLFOX6 or the reverse sequence in advanced colorectal cancer: a randomized GERCOR study. Journal of Clinical Oncology, Vol. 22, No. 2 (January 2004), pp. 229-237, ISSN 1527-7755.

Teufel, A., Steinmann, S., Siebler, J., Zanke, C., Hohl, H., Adami, B., Schroeder, M., Klein, O., Höhler, T., Galle, PR., Heike, M. \& Moehler, M. (2004). Irinotecan plus folinic acid/continuous 5-fluorouracil as simplified bimonthly FOLFIRI regimen for firstline therapy of metastatic colorectal cancer. BMC Cancer, Vol. 4 (July 2004), pp. 38, ISSN 1471-2407.

Vauthey, J. N., Pawlik, T. M., Ribero, D., Wu, T. T., Zorzi, D., Hoff, P. M., Xiong, H.Q., Eng, C., Lauwers, G.Y., Mino-Kenudson, M., Risio, M., Muratore, A., Capussotti, L., Curley, S.A. \& Abdalla, E.K. (2006). Chemotherapy regimen predicts steatohepatitis and an increase in 90-day mortality after surgery for hepatic colorectal metastases. Journal of Clinical Oncology, Vol. 24, No. 13 (May 2006), pp. 2065-2072, ISSN 1527-7755.

Vickers, M., Samson, B., Colwell, B., Cripps, C., Jalink, D., El-Sayed, S., Chen, E., Porter, G., Goel, R., Villeneuve ,J., Sundaresan, S., Asselah, J., Biagi, J., Jonker, D., Dawson, L., Letourneau, R., Rother, M., Maroun, J., Thirlwell, M., Hussein, M., Tehfe, M., Perrin, N., Michaud, N., Hammad, N., Champion, P., Rajan, R., Burkes, R., Barrette, S., Welch, S., Yarom, N. \& Asmis T.. (2010). Eastern Canadian Colorectal Cancer Consensus Conference: setting the limits of resectable disease. Current Oncology, Vol. 17, No. 3 (June 2010), pp. 70-77, ISSN 1718-7729.

Wang, X., Hershman, D.L., Abrams, J.A., Feingold, D., Grann, V.R., Jacobson, J.S. \& Neugat, A.I. (2007). Predictors of survival after hepatic resection among patients with colorectal liver metastasis. British Journal of Cancer, Vol. 97, No. 12 (December 2007), pp.1606-1612, ISSN 0007-0920.

Watkins, D.J., Chau, I., Cunningham, D., Mudan, S.S., Karanjia, N., Brown, G., Ashley, S. \& Norman, A.R. (2010). Defining patient outcomes in stage IV colorectal cancer: A prospective study with baseline stratification according to disease respectability status. British Journal of Cancer, Vol. 102, No. 2 (January 2010), pp. 255-61, ISSN 0007-0920. 
Welsh, F.K., Tilney, H.S., Tekkis, P.P., John, T.G., \& Rees, M. (2007). Safe liver resection following chemotherapy for colorectal metastases is a matter of timing. British Journal of Cancer, Vol. 96, No. 7 (April 2007), pp. 1037-1042, ISSN 0007-0920.

Wicherts, D. A., de Haas, R. J., Sebagh, M., Ciacio, O., Levi, F., Paule, B., Giacchetti, S., Guettier, C., Azoulay, D., Castaing, D. \& Adam, R. (2011a). Regenerative nodular hyperplasia of the liver related to chemotherapy: impact on outcome of liver surgery for colorectal metastases. Annals of Surgical Oncology, Vol. 18, No. 3 (March 2011), pp. 659-669, ISSN 1534-4681.

Wicherts, D. A., de Haas, R. J., Sebagh, M., Saenz Corrales, E., Gorden, D. L., Levi, F., Paule, B., Azoulay, D., Castaing, D. \& Adam, R. (2011b). Impact of bevacizumab on functional recovery and histology of the liver after resection of colorectal metastases. British Journal of Surgery, Vol. 98, No. 3 (March 2011), pp. 399-407, ISSN 0007-1323.

Wicherts, D.A., Miller, R., de Haas, R.J., Bitsakou, G., Vibert, E., Veilhan, L.-A., Azoulay, D., Bismuth, H., Castaing, D. \& Adam, R. (2008). Long-term results of two-stage hepatectomy for irresectable colorectal cancer liver metastases. Annals of Surgery, Vol. 248, No. 6 (Decmber 2008), pp.994-1005, ISSN 0003-4932.

Wong, R., Cunningham, D., Barbachano, Y., Saffery, C., Valle, J., Hickish, T., Mudan, S., Brown, G., Khan, A., Wotherspoon, A., Strimpakos, A.S., Thomas, J., Compton, S., Chua, Y.J. \& Chua, I. (2011). A multicentre study of capecitabine, oxaliplatin plus bevacizumab as perioperative treatment of patients with poor-risk colorectal liveronly metastases not selected for upfront resection. Annals of Oncology Epub (Feb 2011): doi: 10.1093/annonc/mdq714. ISSN 1569-8041.

Yang, A.D., Brouquet, A., \& Vauthey, J.-N. (2010). Extending limits of resection for metastatic colorectal cancer: risk benefit ratio. Journal of Surgical Oncology, Vol. 102, No. 8 (December 2010), pp.996-1001, ISSN 0748-7983. 


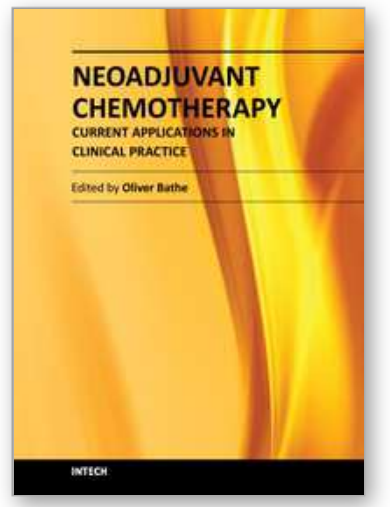

\author{
Neoadjuvant Chemotherapy - Current Applications in Clinical \\ Practice \\ Edited by Dr. Oliver Bathe
}

ISBN 978-953-307-994-3

Hard cover, 268 pages

Publisher InTech

Published online 01, February, 2012

Published in print edition February, 2012

The most significant advances in cancer therapy in recent years have involved the development of systemic therapeutics. With improvements in response rates in solid tumors, opportunities have arisen to enhance the effectiveness of surgery. Administration of systemic therapy prior to surgery - neoadjuvant chemotherapy represents one approach by which clinicians have successfully reduced the extent of surgery and, in some instances, positively impacted on clinical outcomes. This collection of works by expert clinicians from a variety of disciplines represents an exploration of the current knowledge of the role of neoadjuvant chemotherapy in diverse tumor types.

\title{
How to reference
}

In order to correctly reference this scholarly work, feel free to copy and paste the following:

Pamela C. Hebbard, Yarrow J. McConnell and Oliver F. Bathe (2012). Neoadjuvant Chemotherapy for Colorectal Liver Metastases, Neoadjuvant Chemotherapy - Current Applications in Clinical Practice, Dr. Oliver Bathe (Ed.), ISBN: 978-953-307-994-3, InTech, Available from:

http://www.intechopen.com/books/neoadjuvant-chemotherapy-current-applications-in-clinicalpractice/neoadjuvant-chemotherapy-for-colorectal-liver-metastases

\section{INTECH}

open science | open minds

\section{InTech Europe}

University Campus STeP Ri

Slavka Krautzeka 83/A

51000 Rijeka, Croatia

Phone: +385 (51) 770447

Fax: +385 (51) 686166

www.intechopen.com

\section{InTech China}

Unit 405, Office Block, Hotel Equatorial Shanghai

No.65, Yan An Road (West), Shanghai, 200040, China

中国上海市延安西路65号上海国际贵都大饭店办公楼 405 单元

Phone: +86-21-62489820

Fax: $+86-21-62489821$ 
(C) 2012 The Author(s). Licensee IntechOpen. This is an open access article distributed under the terms of the Creative Commons Attribution 3.0 License, which permits unrestricted use, distribution, and reproduction in any medium, provided the original work is properly cited. 